\title{
Learning Through Pictures: The Integration of Reflexive Photography in Social Justice Education
}

\author{
Mary Goitom, MSW, PhD \\ School of Social Work, York University \\ 4100 Keele Street, Toronto, Canada, M3J 1P3
}

Tel: 1-416-736-2100 E-mail: mgoitom@yorku.ca

Received: August 3, 2020 Accepted: September 22, 2020 Published: September 24, 2020

doi: 10.5296/ire.v8i2.17475 URL: https://doi.org/10.5296/ire.v8i2.17475

\begin{abstract}
This article explores the use of reflexive photography as an experiential teaching method in teaching social justice education in an undergraduate social work program. Using critical auto-ethnography as a method, it discusses how this was built into a second-year Bachelor of Social Work (BSW) course by way of planning and application. Drawing on Freire's concept of reflexive practice and based on the experiences of a social work educator teaching this course, the paper describes how (a) the course was designed and executed to realize student knowledge, (b) reaffirm the importance of reflexive practice for knowledge building and (c) for social transformation. On the basis of reflection from its application and student experiences, the author discusses the potential effect that integrating arts-informed teaching methods have on social justice oriented approaches to social work practice, the development of students' practice and professional identity.
\end{abstract}

Keywords: Reflexive photography, Social justice, Experiential learning, Critical pedagogy, Social work practice, Critical auto-ethnography

\section{Introduction}

In the classroom, reflecting on one's practice epitomizes the spirit of being a professional. For instance, "such reflection is evident in mindful introspection, dialogues with peers about relevant critical issues, and more systemic and rigorous participation in action research" (Feucht et al., 2017, p. 234). Nevertheless, reflection on its own does not particularly guarantee practice that is informed by such reflection. Rather, reflexivity can be a support for reflection in action because it is about "finding strategies to question our own attitudes, thought processes, values, assumption, prejudice and habitual actions, to strive to understand our complex roles in relation to others" (Bolton \& Delderfield, 2018, p. 13). Developing such 
skill sets is imperative given the increasing emphasis on social work practice to generate approaches that "seek to validate practice discretion and practice wisdom" alongside the ever increasing bureaucratization of social work practice (D'Cruz et al., 2007, p. 73).

Social work educators are tasked with the responsibility to engage students' capacities to reflect. Students generally possess this ability, as the capacity to reflect is, according to Archer (2010), indispensable to human life. Archer sums up human reflective/reflexive capacity as "the mental capacity that all ... people [possess] to consider themselves in relation to their social contexts; and their social contexts in relation to themselves" (quoted in Johnson, 2011, 12:31). Archer (2010) offers this working definition by first proposing that reflection provides a sense of self that is "necessary for the correct appropriation of rights and duties by those to whom they are ascribed" (p. 281). Second, Archer (2010) elaborates that, in this way, reflection enables the examination and monitoring of actions. Third, she argues that it allows for the careful consideration of the gulf between the actual condition (what is happening) and that of the ideal response as one navigates through society. Given that social work practice requires the investigation of personal values as this has direct implication on direct practice, reflective practice and action taking are the cornerstones of the discipline's education and a necessary skill set for professional development.

Thus, this paper describes the experiences of a social work educator operationalizing Freire's concept of reflexive practice by situating in a reflexive photography assignment in a second-year required BSW groups' course was a useful tool to reaffirm the importance of critical reflexive practice for encouraging knowledge building in students and engaging them in social transformation early in their education. Focused on the process of student learning, the course engages students simultaneously in the theory of and reflection on the meaning of working in groups, the relationship this brings to bear on social change efforts, the challenges students face in this process, and the factors that would help them to overcome these barriers as they move forward. This article will also discuss how reflexive practice assignments can support social work students in their efforts to contribute to social change. By presenting this experience, this paper looks to add to existing scholarship as a possible technique that can be adapted by courses teaching social justice education.

\section{Methodological Approach}

Critical auto-ethnography is the blending of ethnography, auto-ethnography and critical pedagogy. This combination in turn fashions a methodology that allows me using observational memos to analyze my role and integrate it as I investigate a phenomenon (critical reflexive practice) within the context of the group being examined. The meaning given to the phenomenon are understood from the individual and the group perspectives. In this way, I am also a participant in the sense that I can "internalize the researcher gaze and thus examine my Self in the same way that I examine others" (Tilley-Lubbs, 2014, p.3). Reflexivity and introspection guide and facilitate this process as it provides support in gleaning the ways in which the pedagogical intentions of the course was executed and achieves its intended outcomes. As such, I am an actor and participant in this reflection and in my role as author, I write to "understand the significance" (Ellis, 2004, p.68) of what transpired and the "significance or meaning" (Tarres, 2001) that I give to the outcome of the course allows for deeper knowledge to be discovered through introspection and reflection. 
The practice of critical auto-ethnography is a form of self-authorship, a genre of writing and research concerned with displaying the 'multiple layers of consciousness, connecting the personal to the cultural' (Ellis \& Bochner 2000, p.739). It shifts the individual from its external construction to its complex internal ones by way of critical self-reflection and aligns with Freire's (1970) concept of conscientization. Freire postulated that teachers be educated as cultural brokers who have the intention of including the voices that are often excluded and educating those that would become practitioners to practice in the same manner. In this way, the classroom has to be reimaged as a site of collaboration and "this epistemology opens the opportunity to participate" in emancipatory education in which education is conducted in such a way that it fosters intra collaboration between students as opposed to it being done for them (Tilley-Lubbs, 2014, p.6; Street, 2003). This allows for the existence of a counter-hegemonic and counter-institutionalized principle that erases the bridge between the individual and the collective in such a way that it may have the potential to lead to emancipative practice. Therefore, adopting such a framework clarifies that conscientization is not static but rather it is a process that transpires recurrently for student and educator so long as they remain open to "pushing against the grain of norms established by the dominant society" problematizing "actions and practices from a sociocultural perspective" (Tilley-Lubbs, 2014, 6).

\section{Reflexivity and Social Work: A brief overview}

Social work as a profession is concerned with enhancing the social functioning and overall well-being of individuals, families, groups, and communities. Reflective skills then, are invariably considered to be a core element of practice for social workers and an important part of the landscape of social work education (Fook, 1996). A range of different educational sources have influenced the introduction of reflective practice to social workers. For instance, Schön's $(1983,1987)$ work, as influenced by Dewey (1910), can be understood as being primarily concerned with reflection as a tool for the development of practical judgement in professional life. Of value here is how Schön's collaboration with Argyris (1974, 1978) resulted in the application of reflection beyond the academy to professional life. For social work, this generated a useful tool to bridge the gap between theory and practice (Fook, 1996). In adult education, the concept of reflective practice is influenced by the works of Freire (1972), Mezirow (1990, 1991), Brookfield (1993), Brookfield and Preskill (1999) and Boud and Knights (1996), to name a few. These works were instrumental in the introduction of ideas about education as a means for achieving emancipation. The explicit connection between reflection and social justice/change has reformed how transformative work is conceptualized in social work; namely, how education can be considered a key source for such processes to occur thus requiring educators to adopt a critical lens to pedagogy and practice as a means to link the criticality of theory and practice. The inseparability of concepts to such outcomes resulted in the adoption of critical pedagogy as the heading that sees education as a process of liberation and freedom that is rooted in feminist, Marxist, post/decolonial, and post-structuralist theories (see Freire, 1972). Another critical transformation taking place is the use of the term "critical practice" to demonstrate contrast with "reflective practice." The synthesis of existing concepts and ideas within the profession of social work with education theory of critical pedagogy has resulted in a generation of 
unique applications of reflective practice models.

The social sciences have also been instrumental in shaping social work's approach to reflexivity by way of the following four perspectives it presents. The first is concerned with the way bodies of knowledge can refer back to itself in ways that are critical and interrogative. Namely, "reflexivity in this sense initiates a sociology of the discipline's own knowledge base" (Houston, 2015, p. 1). The second details the manner in which reflexivity is particularly engendered in ethnomethodology (Garfinkel, 1991) and symbolic interactionism (Mead, 1967). These two theories, central in sociology, contend with how meaning is socially produced through interaction, communication and social performance (Houston, 2015). Viewed in this way, reflexivity 'is a tool that exposes actors' knowledge, talk and practice to critical analysis rather than taking these areas for granted or seeing them as representing some objective truth" (Houston, 2015, p. 1). The third, referred to by Beck (1992) as reflexive modernization, is aimed at promoting self-actualization and is exemplified in a person's reflection of their lifestyles, identities, opportunities and choices to name a few. The fourth interpretation of reflexivity is to see it as a means to further emancipatory projects (Humphries \& Truman, 1994). Drawing on critical social theory and often applied within qualitative research, reflexivity in this case has been used to demonstrate "how knowledge, norms, roles, social positions, and discourses intertwine with power and how they are also influenced by wider social domains (such as various types of institutions) to enable or constrain life outcomes" (Houston, 2015, p. 2). The aim here is to make clear how people are curbed by structural conditions resulting in restricted life opportunities that then engender social divisions and status injustices. Social work connects with these perspectives and has developed its own specific meaning to reflexivity. The additional understanding that social work offers is as highlighted by D'Cruz et al. (2007) "one where the role of self, cognition, and emotion are subjected to analysis" (Houston, 2015, p. 2). This is key because social workers "need to reflect on their anxiety, ambivalence and fear, especially in situations where a care and control function must be exercised or a statutory remit imposed" (Houston, 2015, p. 2). Simply put, practitioners' meaning-making activities are not value free, rather they are shrouded in power-sodden discourses necessitating that in practice, they critically appraise how they construct their knowledge claims and resulting practices.

Classroom activities that "promote individualised learning and reflection" have the potential to "foster intrapersonal learning during the duration of a course" in addition to supporting students in recognizing "diversity in human experiences" (Mulder \& Dull, 2014, pp. 1017-1018). Journaling as an example, is a popular tool in social work education used to promote self-reflection. Journaling for educators is used as an attempt to bridge the gap between theory and practice, and the "narratives may permit students to write emotionally and to practice self-disclosure, while honing reflective skills" (Mulder \& Dull, 2014, p. 1018). These types of self-reflective assignments solicit personalized faculty responses that provide direction along with thoughtful and constructive feedback. Paramount here is the creation of a learning space that challenges students to think critically so that they may explore theoretical concepts in relation to the practice of social work, allowing for both interpersonal and intrapersonal learning.

Most students express an aversion to theory in their writing, considering it as being far 
removed from their interest in becoming future social workers who are going to "help people." The content of their reflections is indicative of their struggles to connect their coursework as being relevant to their practice. A driving force behind such occurrences is their desire to "get to placement." This leads them to rush through their coursework in ways that prevent them from understanding classroom learning as valuable to and informing their practice learning - thus reinforcing "the age-old problem of linkage between class and field" (Lesser \& Cooper, 2006, p. 134).

This situation raises concerns because this invariably leads to the "overreliance on field work to teach students practice principles, as well as bridge the theory-practice gap, [and create] an unnecessary and unhelpful separation between course work and social work practice" (Wehbi, 2011, p. 494). This concern regarding the gap between theory-practice knowledge in students, reflexivity, and the practicum kindled an ongoing dialogue with two colleagues from other Canadian universities who at the time were also teaching and advising social work students in their field practicums. Our discussions were grounded in the belief that lecturing to students about the importance and imperativeness of these principles (i.e., bridging the gap between theory-practice, and the value of critical reflexivity in this process) is simply not enough but must be demonstrated alongside each other. We discussed our shared concerns and began to identify some pedagogical approaches that might assist us in meeting our outcomes. Namely, we wanted to address the issue by utilizing an approach that would consider the process of learning and the role of content in facilitating an outcome that would challenge the dichotomy between theory and practice and situate it in critical reflexivity as a tool that would facilitate effective and ethical practice central to our undertaking. These discussions led to an ongoing collaboration and engagement with reflexive photography, an alternative approach to reflective journals developed at one of the collaborator's universities. Our project findings have deepened our understanding of an important student learning issue that may assist educators in developing creative approaches to becoming reflexive practitioners. More importantly, we have noted that this project has led to some of our students expressing increased confidence and effectiveness in their practicums. Details of this larger study are published elsewhere (see Oliver, Chalmers \& Goitom, 2019).

\section{Reflexivity and Arts-Informed Approaches}

Though not new, the use of arts-informed approaches in social work education, research and practice has been gaining momentum for two interrelated reasons: (a) the socioeconomic challenges of globalization and the ensuing interconnectedness of the world necessitates that educators, researchers and practitioners adopt new ways of thinking in addressing social issues; and (b) given this, some contend that conventional social work education is poorly prepared skills-wise to address these growing challenges (Leonard et al., 2016; Sinding \& Barnes, 2015). Undoubtedly, the vast majority of the literature notarizing the use of photovoice is not specifically about social work nor is it articulated by social workers. Rather, "despite the evident compatibility with social work's social justice mission, these articles most frequently appear within the realm of public health, nursing, and related health areas" (Peabody, 2013, p. 255). For example, Hergenrather et al. (2009) engaged in a meta-analysis of 31 studies using photovoice as the primary methodology to "promote and enhance individual and community change" (p. 686). They noted that "photovoice can identify 
concerns and priorities that empower participants to become advocates of change for themselves and community, providing data to help influential advocates and policy makers understand the needs of their community" (p. 697). Unfortunately, none of the 31 studies they analyzed referenced nor were published in social work journals.

By comparison and recognizing said critiques as potentially hampering the value and effectiveness of their discipline, there is extensive evidence of the effective use of arts-informed approaches in several academic fields such as sociology, anthropology, nursing, medicine, education, geography, linguistics and leadership development amongst others (Leavy, 2015; McGregor, 2012; Sinding et al., 2012). Such usage across various spheres and disciplines has generated diverse ways in which the effectiveness of arts-based and informed methods is defined. In most instances scholarship discusses the contributions of arts-informed approaches to student learning in relation to its ability to nurture creativity, cultivating deep/critical thinking, engagement and its propensity to guide students toward relationship building as an important mechanism to embarking on developing integrated responses to social issues (Wehbi et al., 2018).

Though much smaller in comparison to other disciplines, academic articles in social work are beginning to report the use and value of photovoice by social work educators and practitioners. For instance, in the realm of practice, Molloy (2007) makes a strong case for photovoice by linking its value in empowering youth in enabling them to convey to adults in their lives their struggles whereas Dumbrill (2008) articulates its usefulness in improving child welfare work with refugees in Canada. The use of photovoice in teaching social work has primarily been used to demonstrate linkages between macro and micro practice at both the undergraduate and graduate levels (see Peabody, 2013; Mulder \& Dull, 2014); experiential learning by way of illustrating the interaction between theory and practice by mainly engaging students with ideas about knowledge and practice (see Wehbi, 2015); as a method of teaching social justice through anti-racist and decolonizing lenses (see Wehbi et al., 2018); effective teaching of research methods (see Bonnycastle \& Bonnycastle, 2015); as a flexible method that responds and attends to the diverse learning needs of students (see Massey et al., 2011); and as a mechanism that promotes self-reflection and students emerging social work identity (see Walton, 2012).

What has been gleaned from these studies is that the incorporation of creative methods of teaching and learning is a resistance to "Eurocentric epistemological foundation that values 'rationality' as a valid form of knowledge" (Wehbi et al., 2018, p. 618). In other words, the incorporation of these creative methods resists and is also met with resistance from dominant paradigm in education that implicitly and explicitly directs teaching "at students" in lieu of "with students" (Etmanski, 2014, p. 5). This suppression of multiple forms of expression invariably stifles social work's ability to provide students with the skills needed to address today's challenges in addition to impeding student's abilities to see themselves reflected in the curriculum (Author, 2019). To this point, the co-creation of knowledge in the classroom allows for multiple forms of knowledge to be built through the incorporation of various perspectives.

Even though as presented above there is "evidence of using arts-informed approaches in education and research in multiple disciplines, including social work, this evidence is largely 
anecdotal relaying experiences of a specific educator or course" (Wehbi et al., 2018, p. 619). For this reason, comprehending how artistic methods can be used in teaching, learning and how to evaluate such an approach remains elusive (Wehbi et al., 2018; Hafford-Letchfield et al., 2012). An attempt to address the evaluation of this approach has generally been tied to the use of text (reflections) to the images taken in an attempt to bridge textual and visual analysis to inform both teaching and practice. The concepts highlighted in the textual analysis of the images begin to demonstrate how integrated into each visual element the concepts taught are and can allow for the creation of larger concept maps to emerge as it relates to the nature of the assignment (i.e., exploration of students' emerging professional identity, practice frameworks for working with youth). Furthermore, in order to develop more comprehensive evaluative methods, "scholarship has started to look for examples of creative methods in other disciplines" thereby "contributing to cross-disciplinary approaches" (Wehbi et al., 2018, p. 619) and moreover encouraging scholarship in social work "to overcome what they see as limitations of their own discipline" and instead embark on the process to understanding the ways in which such methods can enhance research, teaching, learning and practice in social work (Hafford-Letchfield et al., 2012, p. 688).

This paper is a provision to expounding said grounds by presenting a social work educator's experiences with incorporating the use of photography and text to support students in becoming more reflexive and thus better beginning practitioners. To that end, to situate in such beginnings in students, it is imperative to define the differences between arts-informed and arts-based practice as this difference is helpful in understanding the outcome/evolution of this incorporation as demonstrated in students' textual analysis of the images. While related and at times used interchangeably, arts-informed and arts-based practices actually refer to separate forms of practices. Arts-based practices focus principally on art itself and its capacity to impart contemporary understandings of society and its potential for unveiling and leveling oppressive structures (Wehbi et al., 2018). The latter on the other hand, refers to "interventions, research and teaching that, while adopting and integrating elements from the creative arts, are not always about the creation of art or the artistic process per se" (Wehbi et al., 2018, p. 47) but rather are "influenced by, not based in, the arts" (Knowles \& Cole, 2008, p. 59). As such, although it is not distinctly about art itself, said approaches utilize art as method to engage, question, challenge and think through responses/interventions in ways that fosters integrated knowledge production.

Furthermore, this paper provides a demonstration of the integration of arts-informed practice and uses art as a method to spotlight social work and to lead and engage students in an active process of critical reflection and the "doing" of social work practice. To this end, the use of photography in this course engaged students in the process of reflection-on-action (looking out) and reflection-in-action (looking in) (Johns, 1995). By imbuing the structure of the course and assignments with reflection-in-action, students by way of their textual analysis of their photographs engaged in reflection-on-action that supports them to begin to develop important practice skills that are showcased in the text they produce. Thus, engaging students in reflexive practice throughout the course involved constantly having them thinking from within experiences in a way where their experiences in the course necessitates that it is "turned or reflected back upon the mind itself" (Oxford English Dictionary as quoted in 
Bolton \& Delderfield, 2018, p. 14). Reflexivity then as an internal dialogue, asks students to question their attitudes, values, assumptions, habitual actions, thought processes and prejudices to endeavor to comprehend their complex roles in relation to others (Bolton \& Delderfield, 2018). Therefore this "critical focus upon beliefs, values, professional identities, and how they affect and are affected by the surrounding cultural structures, is a highly responsible social and political activity" to practice and this reflection-in-action becomes the gateway to the accompanying textual analysis of the photographs that allows for the emergence of rich final reflection-on-action (Bolton \& Delderfield, 2018, p. 14). In other words, reflection becomes reflexivity when informed and intentional dialogue results in shifts in thinking and practice (Feucht et al., 2017).

\section{The Course}

This course is offered at a school of social work in an urban multicultural city that adopts an explicit critical social work perspective and theoretical orientation in both its undergraduate (BSW) and graduate (MSW, PhD) programs. Immersed in and committed to human rights and social justice, the school consistently teaches applied practice skills throughout its curriculum. In this way, the course illustrates the ways in which the social locations of individuals as well as the social structures contribute to the dislocation of oppressed and disenfranchised populations. Informing this analysis is empowerment and power relations and through its praxis-orientation, the school explicitly links theory with practice and knowledge with action. Thus, emphasis is placed on the importance of critical reflection and the examination of the impact of power relations and social locations on social work practice. The course is situated within this expectation and framework and taught from this orientation. Epistemologically, this course is explicit in its pursuit of disrupting the dichotomous thinking that exists when social justice and group work converge. This "either/or," "all or nothing" thinking includes several options: (a) group leaders facilitate individual change efforts by way of aiding the personal well-being and healing of their membership; or (b) group leaders engage in advocacy and social change efforts (a particular political ideology is embraced in this work); or (c) group leaders must engage in political action; or (d) group leaders' failure to engage is to not embrace social justice consciousness (Roysircar, 2006). In its design, this course acknowledges and situates "the extent to which group practice is rooted in social justice values of equity, access, and participation" (Singh \& Salazar, 2010, pp. 97-98). To this end, social justice consciousness and competency are viewed as a continuum, whereby at one end of the spectrum there exists knowledge about inequities and oppression along with ongoing critical self-reflexivity on how privilege, issues around ethnicity, power, and race coalesce in one's own life (Constantine et al., 2007). On the other end of the continuum, there "are system intervention and advocacy skills promoting social change" (Singh \& Salazar, 2010, p. 98). By definition, students are taught, for example, that effective clinical practice (micro level) that emphazises empowerment and self-determination are incomplete for social transformation if problems are experienced individually without recognizing that the issues are in fact part of a larger systemic problem experienced by many. The course asserts that through critical reflexivity, group work rooted in social justice "can enact social justice consciousness at any point along the continuum, depending upon the needs of the group members and the context in which the group takes place” (Singh \& Salazar, 2010, p. 98). 
This is a practice-intensive course that uses a variety of small and large in-class group activities as well as reciprocal and experiential learning to achieve the learning objectives. In terms of the latter, students participate as members of small working groups through the duration of the course. Within the context of their small working groups, students are given opportunities to apply critical perspectives, approaches, and skills during their interactions. This is achieved by students coming prepared for class (i.e., having read assigned readings and preparing two to three questions for discussion), listening to a lecture, and participating in the in-class group activities that correspond to the week's learning. Topics of study are taught in an integrative manner that "map" practice skills across the contexts of small groups, communities, and social movements.

The course runs three hours per week for 12 weeks in the fall semester, has an offering of five sections with approximately 40 students enrolled in each section. Two sections of the course are taught by the author and two by contract faculty. All sections use the same teaching material. Contract faculty are trained by the author and support is provided to them throughout the semester. Students vary in age $(18+)$, are diverse in their ethno-racial composition, class, sexual orientation, and entry into social work. Furthermore, given the age range, the diverse pool of students, and the different level of entry into social work, it is not uncommon to have some students who have experience in or are active in various types of social justice movements. This involvement has ranged from disability rights activism, anti-poverty work, mad activism, and anti-racist organizing. This paper strictly contends with the experiences and learnings gleaned from the two sections taught by the author.

\section{The Assignments}

There are three assignments in this course: (a) an advocacy letter; (b) group practice - community development and organizing for change; and (c) reflexive photography. Each assignment builds on the other to ensure that the concepts integrated in this course are experienced to develop a more visceral learning. Assignments are constructed in ways that center and explicitly remind students that social workers are located within the context of groups across local and global social service, community, and social policy settings. As such, the assignments introduce them to skills that can help them relate to themselves and to others more constructively and help them experience growth through communal action. For example, their first assignment - the advocacy letter - is designed to support students in learning how to operationalize advocacy work with marginalized individuals and communities. Students are tasked with identifying a social issue of interest, studying its root causes and the ways in which individuals/communities have been affected (i.e., policy, access), and writing a one-page advocacy letter to policymakers. Beyond the mechanics of how to write a letter which includes audience, argument, evidence, and hybrid writing, the real challenge lies in learning about the "risks of speaking" and how to do it; in other words, who has the right to "speak," how do you "speak" on behalf of others, or how do you use language that does not fetishize the issue or infantilize individuals/communities?

Their second assignment builds on the challenges posed by their first assignment and here students are provided a framework that helps them better understand the extent to which social justice is actualized through group work. The framework outlines how social justice is not just a goal to be attained but also a process that requires developmental stages. Students 
continue to focus on the social issue chosen for their first assignment and identify a corresponding social movement or a social organization working towards addressing the issue. As a unit, students develop a plan to mobilize political forces to ameliorate this problem in ways that could actually be implemented. The plan, for example, may be in support of an already existing initiative undertaken by the chosen social movement or a social service organization, or it may be based entirely on an independent action organized by the students in their groups.

Within this exercise, reflective practice, reflexivity, and critical reflection are necessary tools that support how this framework functions, as they are the core aspects of social work practice that "enhance or complement formal theories and proceduralized practice" (D'Cruz et al., 2007, p. 74). To be effective in the course and to successfully develop the skill sets necessary for critical group work practice, students are engaged in reflexivity and encouraged to practice how their learning from this "self" process can further group-level work. In this way, reflexivity as a group-level construct is understood and practiced as the "extent to which group members overtly reflect upon, and communicate about the group's objectives, strategies (e.g., decision-making) and processes (e.g., communication), and adapt them to current or anticipated circumstances" (West, 2000, p. 296). Students are strongly encouraged to record in detail their experiences as this record will become the source they draw from to complete their final assignment - reflexive photography, which is specifically situated to bring to the fore their experiences and learning.

Reflexive photography is modified from a qualitative research method called photovoice (Wang \& Burris, 1997), a method that has been used in local communities, practice, and activist settings throughout Canada and internationally as a participatory health promotion and research strategy. Reflexive photography gives students a unique format in which to document and give voice to their learning; specifically, it allows students to record, reflect on, and communicate their understanding and experiences of group work, community, and activism based on what they have learned throughout the course. The essence of this strategy is ensconced in the principles of Paulo Freire (2000) and feminist theory (Weiler, 1988 ) and is conceived "as a process of awakening critical consciousness and enhancing its development," all of which is imperative in order to activate and accomplish social change (Peabody, 2013, p. 252).

Feminist theories contend with issues of power and representation and explicitly state that "power accrues with those who have voice, determine what language is used, write history, and participate in decisions" (Molloy, 2007, p. 42). Feminist theories can shift power to where it is more equitably distributed and in this process individual's subjective experiences are acknowledged and centered. Photovoice adopts this theory in practice in two fundamental ways: (a) through images and conversations, it redistributes power to those who normally would not be heard from or included in the decision-making processes; and (b) the images and conversations become and are enduringly used as historical documentation (Molloy, 2007).

The Freirian method holds that it is through dialogue and critical reflection about the material conditions of their everyday lives that people themselves can begin to see their circumstances as socially and politically constructed. Freir 
"submergence" in the reality of oppression and named the perceiving of one's situation as having no exit or resolution as "the circle of certainty" thus obscuring the problem from being understood as structural (pp. 36-37, 89). Without critical dialogue between people and communities, people remain obscured from being able to name their experiences and its causes, and for Freire, it is through the development of critical consciousness that people can come together to take action for the accomplishment of social change. In this way, Freire "used words and language as part of a literacy movement to enable people to capture the contradictions embodied in their daily lives" (Peabody, 2013, p. 253).

Like the Freirian method, photovoice asks people or members of communities to use photographs to document their social, political, and economic realities and advocate for social change and social justice. This approach has been used as both a research method and a grassroots sounding board to communicate one's place in the world. In line with these philosophies, students in the course contend with the following questions: In what ways have the course concepts, topics, class activities, working groups I have been part of influenced my future career in social work? What is the relationship between group work and social justice? How has my understanding of social work and social work practice been altered? How has my self-understanding changed? What skills will I be taking with me and why?

In the first part of the assignment, students are required to use digital cameras or cell phone cameras to document their learning and to address questions regarding both the content and the context of the photos they take. Ethical practice surrounding the taking of photographs is discussed with students before they begin this assignment. Students learn that the photographs they take must be their own original work (i.e., not pictures available through public domains such as the internet); they can use a photograph of themselves because they can provide consent to use the image; they can utilize a picture they take from an event that is public; and last, for ethical reasons surrounding consent, they are not to take photographs of people on the street, or in their workplaces. Students discover quickly that selecting photographs that embody one's views and experiences of group work, community, and activism is often more difficult than it may seem. As such, they are assigned with taking a suite of photographs of something related to the practice of social work in the context of group work, activism, or community (or key learnings for them in this area). From the suite of photographs they have taken, they are then to narrow it down to two images that capture and represent what group work, community, and activism mean to them as future practitioners, particularly how this has evolved throughout the course. To support them in this process, students ask contextual questions such as: What is the meaning of this photograph? How do I understand what is going on? What do I bring to my reading of this photograph? How is my reading informed (and biased) by my knowledge? (Phillips \& Bellinger, 2011). This is in line with the Freirian process of "problem posing" where students reflect on the insight they glean from these questions thus supporting them to engender a critical consciousness through reflection on fundamental issues of power in their everyday lives. Problem-solving education supports people as they "develop their power to perceive critically the way they exist in the world with which and in which they find themselves; they come to see the world not as a static reality, but as a reality in process, in transformation" (Freire, 2000 , p. 64, emphasis in original). Furthermore, students reflect on their own experiences 
(learning in the classroom and beyond) and continue to engage in a critical analysis of the sources of the issues they have been exploring throughout the course and their role and responsibilities as future practitioners. In this way, students are encouraged to explore additional meanings and to go beyond the content of the photographs; this exploration is demonstrated in the second part of the assignment.

In the second part of the assignment, the reflexive journal, students are asked to write a reflexive paper. Reflexivity is defined as the ability to act in the world and to critically reflect on our actions in ways that may reconstitute how we act and reshape the nature of our professional identity. It involves becoming aware of the practice assumptions that underlie how we make sense of practice situations with the ultimate aim of becoming "vigilant about our practices" (Spivak, 1984-85, p. 184). In a minimum of six pages, students write, discuss, and connect the images from part one of the assignment to their learning and reflect on what they are taking away from this experience. In this manner, the photographs can stimulate unique interpretations, discussion, and analysis that can be shared and explored with the instructor through the marrying of image and text. The use of photographic images has the potential to shift the nature of the discussion in the text to become both symbolic and metaphoric (Phillips \& Bellinger, 2011). This can facilitate powerful learning opportunities as the assignment permits capturing "in-the-moment" experiences as a visual and text document that can be revisited by the students once the course is completed and as they continue their process of learning.

\section{Reflection}

This course was designed with the intent to operationalize Freire's concept of reflexive practice by situating in teaching strategies that would support students in developing their professional identity in a manner that would enhance their ability to engage in critical reflexivity and understand as well as utilize such capabilities as integral to their social work practice. The reflexive photography assignment was chosen as an innovative tool to advance this intention, and the other two assignments were implemented as complements to strategically support and intensify/reinforce the potential learning that reflexive photography has to offer students. From the experiences of a social work educator operationalizing said concept, three key learnings were developed from students for the author by way of the reflexive photography assignment. First, the author observed that students provided rich insights about the value of the coursework in illuminating the ways in which the ideology of individualism compromises the foundation of social work theory and practice. Second, from observational memos, it was gleaned that the creative nature of the approach to critical reflection allowed for the integration of parts of themselves that they normally would not have conceived as being useful for practice and, as a result, I noticed that they began to articulate how this linked to social work practice. Third, through this process, the analysis of my observational memos revealed that they began exploring and working out the ways in which they would like their own values individually and as part of the collective to be oriented to their practice. The intention is not to present the dissemination of my learning linearly but to allow for as much comprehensive understanding as possible of these developments. Thus, these three points will be presented "separately." It should therefore be 
noted that from an experiential standpoint, these learnings are, in fact, very much interconnected.

When it comes to the call of the profession, the Canadian Association of Social Workers Code of Ethics utilizes language that articulates that the focus is on individual/group well-being with professionals in the field being tasked with acquiring the necessary skills needed to problem solve and achieve social justice. One such prominent skill set that is needed across the gambit of social work practice is advocacy. Through advocacy social workers use their position of liaising between clients and institutions of dominant structures to actively transform these structures in a manner that fosters social justice for the individual. For the most part, this is how the profession is marketed and therefore understood by a good subset of students entering university to become professional social workers. With this understanding in mind, "helping the person" and "wanting to make positive changes in their lives" by being "that" person for people is what I discovered how some students articulated in their reflexive photography assignment, how they are conceptualizing social work, advocacy, and social justice.

Through the assignment, I was able to observe how the coursework led to the understanding that, although "social work is commissioned with the task of improving the lives of oppressed people," paradoxically, it does this by "simultaneously working within structures that function to maintain oppression" (Nichols \& Cooper, 2011, p. 85). This awareness was a surprise learning for me as it was a departure from the ways in which students had initially conceptualized social work. This was because students, I learned, came to recognize that for them to engage in social transformation meaningfully as social workers, the practice of social work needs to undergo fundamental change in form or nature and this cannot happen without concurrently challenging the structure within which the discipline exists. At the same time, this discovery necessitates that the profession critically examine its identity by way of challenging the fundamental assumptions that constitute its raison d'être. Beyond the students, I understood this to also be imperative for anyone wanting to join the profession, as they too it seemed need to examine their ontological and epistemological subject positions. It is the coming together of these factors as gleaned from my observations-social work identity and the individual's identity - that continues to socially construct the profession.

From my memos of class discussions, observations and assignments, students also identified how the ideology of individualism has shaped how they conceptualized the profession and their sense of social issues, what their roles would be, and how they ultimately came to understand who they are. It appears that students came to recognize how the interlocking architecture of individualism and capitalism have developed to powerfully influence and shape how they understand the world and themselves in it. For instance, from my memos, it became clear that the values they identified as symbiotically conveying the framework of individualism include notions of independence, selfhood, and self-reliance. Though they are worthwhile values to have, the concern from the analysis of my memos it appears is the way in which they have become excessive, overarching, and presented as being above all that generates concern. This, in essence, it was gleaned distorts how they understand themselves and society because, "in this core system, individuals approach their selfhood, conceptually, 
as being separate from society rather than constituted socially" (Nichols \& Cooper, 2011, p. 86).

In this climate, social work practice, according to students' reflections, is designed to increasingly address social problems in a manner that overemphasizes the "atomized individual self" (Zaretsky, 1986). From my observations, it was clear that it was at this juncture that they began to reconceptualize some practice modalities, particularly in the area of family therapy and child welfare. Some of the reimagining that I noted was taking root was in how the individualization of care and the personalization of services are indicative of societal trends that demonstrate how individualism has a notable impact on social work. While the personalization and individualization of care are important for service users to articulate their desires for a better future, from my memos I noticed that for students when individualism is taken too literally it can undermine social relations by abating the "textured, nuanced problem-solving experience of community" (Selznick, 1998, p. 5), whilst "thwarting social work's ability to effectively engage in participatory democratic processes as a means of tackling social problems as their structural foundations" (Nichols \& Cooper, 2011, p. 87). At the heart of the conflict from my observations is their ability to recognize the extent to which the ideology of individualism has been internalized by them and how this shapes how they understand themselves, society, social problems, service users and social work. Within this, what is key is the need to recognize how to practice social work in a way that acknowledges the give-and-take between the individual and the collective spheres in order to enhance the well-being of both.

This shift in thinking, coupled with the injection of a creative approach to critical reflection, I noticed allowed students to integrate parts of themselves that they normally would not have conceived as being useful for practice. The experiential learning nature of the course demands that students "get out of their heads" and delve into the experience of integrating theory and practice. Experiential learning pedagogy is incorporated into the course so as to make learning less abstract by engaging creative practice modalities. This was achieved by providing as much concrete experience as possible, such as hands-on activities and assignments so as to allow the learner to " "grasp' the fundamental building blocks of the intended new knowledge or skill” (Cheung \& Delavega, 2014, p. 1072).

With Kolb and Kolb's (2009) model of the experiential learning cycle as a starting point, reflexive practice was an ongoing process that required students to engage in critical thinking, namely, thinking about the experience, reflecting on their own experience and its connection to concepts and actions. This required students and I to conceptualize how abstract thinking and real-life situations were linked to one another and through this, surprisingly I noted they began to understand the skills and knowledge that was being learned. For example, according to my memos, through the second and final assignment, I noticed that they began to utilize "the acquired knowledge and practical insight to plan future actions" and continuously engage in such experiential practices by applying knowledge, "creating new interpretations or dimensions to the knowledge or skills that are now integrated" (Cheung \& Delavega, 2014, p. 1072). I noted that what was helpful in beginning to usher this in for students and I was the alignment between the course content and the school's critical orientation engaging in a decolonial process of knowledge production in the learning process provided a critical 
framing of the etiology and ontology of knowledge. Therefore, it introduced a creative practice orientation and was integrated into all facets of the course which allowed for the demonstration of how arts-informed approaches can link to practice and to examine the ways in which it can have implications in the development of interventions in social work.

Last, I noted a shift in lectures, discussions and their reflective writing exercise in how students discussed how they were now beginning to explore the ways in which they want these new values, conceived as individual and collective, to orient their future practice. In my analysis of these memos, I noticed how the integration of arts-informed approaches allowed for not only identification of the invisible rules that influence how learning then practice in the field occurs but also how necessary it was as a tool to challenge such modalities. For instance, it was surprising to note that some were able to link this practice to knowledge production and how it is defined, by whom, and to what end - and how this does not always contribute to social justice oriented interventions at the micro, meso, and macro levels. Furthermore, from my memos, a student who intends to practice in child welfare discussed how she is now reconceptualizing how she might practice in this sector by orienting her thinking to ask, "How can I reimagine child welfare from a community-based critical and decolonizing perspective? What would I change, maintain, strengthen and why? What do I have to do to achieve this and what do I need?"

Based on my experiences, it has become apparent to me that perhaps arts-informed practice "can facilitate the design and development of helping interventions in social work to meld diverse forms of knowledge building with multiple methods of representation," and as such is becoming a useful tool to intervene and advance strategy in "social work whether those involve direct provision of support of people who experience serious social issues, community action and organisational development, or policy change" (Moxley \& Feen, 2016, p. 1690; see Bonnycastle \& Bonnycastle, 2015; Etmanski, 2014; Hafford-Letchfield et al., 2012; Leonard et al., 2016; Wehbi, 2011, 2018). What I have gleaned from the integration of reflexive photography in this course is that it has the capacity to contribute to a different way of conceptualizing the human experience in ways that vary to the traditional evaluative methods by actively affiliating the classroom and practice setting. It can do this by opening the door to exploring and utilizing various modes of knowledge acquisition and skills applications by bridging the divide between knowing what and applying how (Cheung \& Delavega, 2014). This consociation materializes because the doing is connected with theoretical knowledge.

\section{Conclusion}

Based on the experiences of a social work educator operationalizing Freire's concept of reflexive practice, this article discussed how a reflexive photography assignment was a useful teaching tool to better engage students in the practice of critical reflexivity so as to support them in the process of knowledge building and social transformation early in their social work education. From this experience, the instructor observed how this method was supportive in helping them begin to consider ways in which they can inaugurate creative responses to the ever-evolving practice climate and how the use of photography can potentially be a source for possible social transformation. Such incorporation it was noted provided the opportunity to critically reflect on the self, the profession, society, and the 
meaning of transformation, and it was also a useful tool in engaging students with new skills that they can utilize in their practice. Conjointly, the social justice orientation of the course and the learning through the use of photovoice it was found exposed students to participatory action research and allowed them to consider the ways in which they can harness collective power to transform and better serve individuals and communities.

\section{References}

Archer, M. S. (2010). Routine, reflexivity, and realism. Sociological Theory, 28(3), 272-303. https://doi.org/10.1111/j.1467-9558.2010.01375.x

Argyris, C., \& Schön, D. (1974). Theory in practice: Increasing professional effectiveness. San Francisco, CA: Jossey-Bass.

Argyris, C., \& Schön, D. (1978). Organizational learning: A theory of action perspective. Reading, PA: Addison Wesley.

Beck, U. (1992). Risk society: Towards a new modernity. London: Sage.

Bolton, G., \& Delderfield, R. (2018). Reflective practice: Writing and professional development. Thousand Oaks, CA: Sage.

Bonnycastle, M. M., \& Bonnycastle, C. R. (2015). Photographs generate knowledge: Reflections on experiential learning in/outside the social work classroom. Journal of Teaching in Social Work, 35(3), 233-250. https://doi.org/10.1080/08841233.2015.1027031

Boud, D., \& Knights, S. (1996). Course design for reflective practices: Research, theory and practice. In N. Gould \& I. Taylor (Eds.), Reflective learning for social work (pp. 23-46). Aldershot, England: Ashgate.

Brookfield, S. (1993). Through the lens of learning: How the visceral experience of learning reframes teaching. In D. Boud, R. Cohen, \& D. Walker (Eds.), Using experience for learning (pp. 21-32). Buckingham, England: Open University Press.

Brookfield, S., \& Preskill, S. (1999). Discussions as a way of teaching: Tools and techniques for university teachers. Buckingham, England: The Society for Research into Higher Education and Open University Press.

Canadian Association of Social Workers (CASW). (2005). Code of ethics. Retrieved from https://www.casw-acts.ca/sites/default/files/attachements/casw_code_of_ethics.pdf

Cheung, M., \& Delavega, E. (2014). Five-way experiential learning model for social work education. Social Work Education: The International Journal, 33(8), 1070-1087. https://doi.org/10.1080/02615479.2014.925538

Connolly, M., \& Harms, L. (2012). Social work: From theory to practice. Melbourne, Australia: Cambridge University Press. https://doi.org/10.1017/CBO9781139192521

Constantine, M. G., Hage, S. M., Kindaichi, M. M., \& Bryant, R. M. (2007). Social justice and multicultural issues: Implications for the practice and training of counselors and counseling psychologists. Journal of Counseling and Development, 85, 24-29. https://doi.org/10.1002/j.1556-6678.2007.tb00440.x

D'Cruz, H., Gillingham, P., \& Melendez, S. (2007). Reflexivity, its meanings and relevance for social work: A critical review of the literature. British Journal of Social Work, 37, 7390. https://doi.org/10.1093/bjsw/bc1001 
Dewey, J. (1910). How We Think. Lexington, MA: D.C. Heath and Company. https://doi.org/10.1037/10903-000

Dumbrill, G. C. (2008). Your policies, our children: Messages from refugee parents to child welfare workers and policymakers. Child Welfare, 88(3), 145-168.

Ellis, C. (2004). The ethnographic I: A methodological novel about autoethnography. Walnut Creek, CA: AltaMira Press.

Ellis, C. \& Bochner, A. (2001). Autoethnography, personal narrative, reflexivity: Researcher as subject. In N. Denzin \& Y. Lincoln (Eds.), Handbook of qualitative research (pp. 733-768). Thousand Oaks, CA: Sage.

Etmanski, C. (2014). Creating the learning space: Teaching the arts in CBR. In C. Etmanski, B. L. Hall, \& T. Dawson (Eds.), Learning and teaching community-based research: Linking pedagogy to practice (pp. 265-284). Toronto, ON: University of Toronto Press. https://doi.org/10.3138/9781442699397-019

Feucht, F. C., Brownless, J. L., \& Schraw, G. (2017). Moving beyond reflection: Reflexivity and epistemic cognition in teaching and teacher education. Educational Psychologist, 52(4), 234-241. https://doi.org/10.1080/00461520.2017.1350180

Fook, J. (1996). The reflective researcher: Developing a reflective approach to practice. In Fook, J. (Ed.), The reflective researcher: Social workers' theories of practice research (pp. 1-8). St. Leonards, NSW, Australia: Allen \& Unwin.

Freire, P. (1972). Pedagogy of the oppressed. Harmondsworth, England: Penguin.

Freire, P. (2000). Pedagogy of the oppressed (30th anniversary ed.). New York, NY: Continuum Publishing.

Garfinkel, H. (1991). Studies in ethnomethodology. London, England: Wiley. https://doi.org/10.1017/CBO9780511611827.003

Hafford-Letchfield, T., Leonard, K., \& Couchman, W. (2012). "Arts and extremely dangerous": Critical commentary on the arts in social work education. Social Work Education: The International Journal, 31(6), 683-690. https://doi.org/10.1080/02615479.2012.695149

Hergenrather, K., Rhodes, S. D., Cowan, C. A., \& Bardhoshi, G. (2009). Photovoice as community-based participatory research: A qualitative review. American Journal of Health Behavior, 33(6), 686-698. https://doi.org/10.5993/AJHB.33.6.6

Houston, S. (2015). Enabling others in social work: Reflexivity and the theory of social domains. Critical and Radical Social Work, 3(2), 245-260. https://doi.org/10.1332/ 204986015X14302240420229

Humphries, B., \& Truman, C. (Eds.). (1994). Re-thinking social research. Aldershot, England: Avebury

Johns, C. (1995). Framing learning through reflection within Carper's fundamental ways of knowing in nursing. Journal of Advanced Nursing, 22(2), 226-234. https://doi.org/10.1046/j.1365-2648.1995.22020226.x

Johnson, M. (2011, May 12). Margaret Archer on reflexivity. [Video File]. Retrieved from https://www.youtube.com/watch?v=bMpJ5wnuB64

Knowles, J. G., \& Cole, A. L. (2008). Arts-informed research. In J. G. Knowles \& A. L. Cole 
(Eds.), Handbook of the arts in qualitative research (pp. 55-70). London, England: Sage. https://doi.org/10.4135/9781452226545.n5

Kolb, A.Y., \& Kolb, D.A. (2009). The learning way Meta-cognitive aspects of experiential learning. Simulation \& Gaming, 40, 297-327. https://doi.org/10.1177/1046878108325713

Leavy, P. (2015). Method meet art: Arts-based research practice (2nd ed.). New York, NY: Guildford Publications.

Leonard, K., Hafford-Letchfield, T., \& Couchman, W. (2016). The impact of the arts in social work education: A systematic review. Qualitative Social Work, 17(2), 286-304. https://doi.org/10.1177/1473325016662905

Lesser, J. G., \& Cooper, M. (2006). Theory and practice: An integrative model linking class and field. Journal of Teaching in Social Work, 26(3-4), 121-136. https://doi.org/10.1300/J067v26n03_08

Massey, M. G., Kim, S., \& Mitchell, C. (2011). A study of the learning styles of undergraduate social work students. Journal of Evidence-Based Social Work, 8(3), 294-303. https://doi.org/10.1080/15433714.2011.557977McGregor, C. (2012). Art-informed pedagogy: Tools for social transformation. International Journal of Lifelong Education, 31(3), 309-324. https://doi.org/10.1080/02601370.2012.683612

Mead, G. H. (1967). Mind, self and society. Chicago, IL: Chicago University Press.

Mezirow, J. (1990). Fostering critical reflection in adulthood: A Guide to transformative and emancipatory learning. San Francisco, CA: Jossey-Bass.

Mezirow, J. (1991). Transformative dimensions of adult learning. San Francisco, CA: Jossey-Bass. https://doi.org/10.1177/104515959100300116

Molloy, J. K. (2007). Photovoice as a tool for social justice workers. Journal of Progressive Human Services, 18(2), 39-55. https://doi.org/10.1300/J059v18n02_04

Moxley, D. P., \& Feen, H. (2016). Arts-inspired design in the development of helping interventions in social work: Implications for the integration of research and practice. British Journal of Social Work, 46(6), 1690-1707. https://doi.org/10.1093/bjsw/bcv087

Mulder, C., \& Dull, A. (2014). Facilitating self-reflection: The integration of photovoice in graduate social work education. Social Work Education, 33(8), 1017-103. https://doi.org/10.1080/02615479.2014.937416

Nichols, L. C., \& Cooper, L. B. (2011). Individualism and its discontents in social work: Proposing a counternarrative for a new vision of social work theory and practice. Journal of Progressive Human Services, 22(1), 84-100. https://doi.org/10.1080/10428232.2011.565508

Oliver, B., Chalmers, D. \& Goitom, M. (2019). Reflexivity in the Field: Applying Lessons Learned from a Collaborative Scholarship of Teaching and Learning Study Exploring the Use of Reflexive Photography in Field Education. In J. Friberg \& K. McKinney (Ed.), Applying the Scholarship of Teaching and Learning Beyond the Individual Classroom. Bloomington, IN: Indiana University Press. https://doi.org/10.2307/j.ctvpb3w0t.5

Peabody, C. G. (2013). Using photovoice as a tool to engage social work students in social justice. Journal of Teaching in Social Work, 33(3), 251-265. https://doi.org/10.1080/088 41233.2013.795922 
Phillips, C., \& Bellinger, A. (2011). Feeling the cut: Exploring the use of photography in social work education. Qualitative Social Work, 10(1), 86-105. https://doi.org/10.1177/1473325010361999

Roysircar, G. (2006). A theoretical and practice framework for universal school-based prevention. In R. L. Toporek, L. H. Gerstein, N. A. Fouad, G. Roysircar, \& T. Israel (Eds.), Handbook for social justice in counseling psychology: Leadership, vision, and action (pp. 130-145). Thousand Oaks, CA: Sage. https://doi.org/10.4135/9781412976220.n10

Schön, D. A. (1983). The reflective practitioner: How professionals think in action. London, England: Temple Smith.

Schön, D. A. (1987). Educating the reflective practitioner: Toward a new design for teaching and learning in the professions. San Francisco, CA: Jossey-Bass.

Selznick, R. (1998). Foundations of a communitarian liberalism. In A. Etzioni (Ed.), The essential communitarian reader (pp. 3-14). Lanham, MD: Rowman \& Littlefield.

Sinding, C., Paton, C., \& Warren, R. (2012). Social work and the arts: Images at the intersection. Qualitative Social Work, 13(2), 187-202. https://doi.org/10.1177/14733 25012464384

Sinding, C., \& Barnes, H. (2015). Social work artfully: Beyond borders and boundaries. Waterloo, ON: Wilfrid Laurier University Press.

Singh, A., \& Salazar, C. F. (2010). The roots of social justice in group work. The Journal for Specialist in Group Work, 35(2), 97-104. https://doi.org/10.1080/01933921003706048

Spivak, G. C. (1984-85). Criticism, feminism and the institution. Thesis Eleven, 10/11, 175-189. https://doi.org/10.1177/072551368501000113

Street, S. (2003). Representación y reflexividad en la (auto)etnografía crítica: ¿Voces o diálogo? Nómadas, 18, 72-79.

Tarrés, M. L. (2001). Observar, escuchar y comprender: Sobre la tradición cualitativa en la investigación social. Porrúa, Mexico: Facultad Latinoamericana de Ciencias Sociales, El Colegio de México.

Tilley-Lubbs G.A. (2016). Critical Autoethnography and the Vulnerable Self as Researcher. In Tilley-Lubbs G. A., Calva S. B. (eds) Re-Telling Our Stories. Imagination and Praxis (Criticality and Creativity in Education and Educational Research) (pp. 3-15). SensePublishers, Rotterdam. https://doi.org/10.1007/978-94-6300-567-8_1

Walton, P. (2012). Beyond talk and text: An expressive visual arts method for social work education. Social Work Education, 31(6), 724-741. https://doi.org/10.1080/02615479. 2012.695934

Wang, C., \& Burris, M. A. (1997). Photovoice: Concept, methodology, and use for participatory needs assessment. Health Education Behavior, 24(3), 369-387. https://doi.org/10.1177/109019819702400309

Wehbi, S. (2011). Reflections on experiential teaching methods: Linking the classroom to practice. Journal of Teaching in Social Work, 31(5), 493-504. https://doi.org/10.1080/ 08841233.2011.614205

Wehbi, S. (2015). Arts-Informed Teaching Practice: Examples from a Graduate 
Anti-Oppression Classroom. Social Work Education, 34(1), 46-59. https://doi.org/10.1080/02615479.2014.937417

Wehbi, S., El-Lahib, Y., Perreault-Laird, J., \& Zakharova, G. (2018). Oasis in a concrete jungle: arts-informed methods in social work classrooms. Social Work Education: The International Journal, 37(5), 617-632. https://doi.org/10.1080/02615479.2018.1450372

Weiler, K. (1988). Women teaching for change: Gender, class, and power. South Hadley, MA: Bergin \& Garvey.

West, M. A. (2000). Reflexivity, revolution and innovation in work teams. In D. A. Johnson \& S. T. Beyerlein (Eds.), Advances in the interdisciplinary study of work teams: Product development teams. Stamford, CT: JAI Press.

Zaretsky, E. (1986). Capitalism, the family, and personal life. New York, NY: Harper \& Row.

\section{Copyright Disclaimer}

Copyright reserved by the authors.

This article is an open-access article distributed under the terms and conditions of the Creative Commons Attribution license (http://creativecommons.org/licenses/by/4.0/). 